Transportation Research Forum

Book Review: Aviation Infrastructure Performance: A Student in Comparative Political Economy

Book Editors(s): Clifford Winston and Ginés de Rus

Review Author(s): Steven Martin

Source: Journal of the Transportation Research Forum, Vol. 48, No. 1 (Spring 2009), pp. 117-120

Published by: Transportation Research Forum

Stable URL: http://www.trforum.org/journal

The Transportation Research Forum, founded in 1958, is an independent, nonprofit organization of transportation professionals who conduct, use, and benefit from research. Its purpose is to provide an impartial meeting ground for carriers, shippers, government officials, consultants, university researchers, suppliers, and others seeking exchange of information and ideas related to both passenger and freight transportation. More information on the Transportation Research Forum can be found on the Web at www.trforum.org. 
Winston, Clifford, and de Rus, Ginés, eds. Aviation Infrastructure Performance: A Study in Comparative Political Economy. Washington, D.C.: Brookings Institution Press, 2008. ISBN 9780-8157-9395-3.

\section{Aviation Infrastructure Performance}

\section{by Steven Martin}

In the late $20^{\text {th }}$ century, facing what was then considered to be high levels of fiscal pressures and beginning to recognize that performance could be made more efficient, various national governments began to look more closely at alternative ways to provide infrastructure. Although the United States has largely resisted these pressures to date (in no small part because of political pressures originating with labor groups), several other developed countries have embraced varying forms of privatization, corporatization, regulation, and reform. Transportation and utilities were among the first industry groups to be reformed.

Winston and de Rus have assembled a highly readable overview of the economic desirability of privatizing aviation infrastructure - mostly airport services. The essays that they collected into a relatively short, nine-chapter book, review different national examples of "non-traditional" structures for providing aviation services. The nations examined vary in the extent to which their air systems suffer from the type of congestion and delay that characterize the United States. They also vary in the extent to which their airports are corporatized, their ability to fund investment, and the national institutions and political arrangements that oversee or regulate their performance. These illuminate how different institutions affect aviation economic performance.

The book is divided into three major sections. Part one addresses aviation policy in the United States and European Union - areas which generally provide aviation infrastructure through the public sector. Part two discusses countries that are experimenting with varying forms of privatization Australia, New Zealand, the United Kingdom, and Canada. Part three discusses air transportation in China and developing countries - areas just beginning to examine private participation in aviation infrastructure.

Morrison and Winston describe the evolution of U.S. aviation policy towards airports and air traffic control systems and argue for greater privatization of both. In their view, the congestion and delay that have virtually become defining characteristics of the U.S. system are "a manifestation of the failure of publicly owned and managed airports and air traffic control to adopt policies and introduce innovations that could greatly improve the efficiency of the ... system." They maintain that privatized airports and air traffic control would have the potential to improve service, reduce costs, and maintain safety at least in part because they would be less constrained by political influences (i.e., public finance and congressional intervention) and appropriately incentivized by competitive forces.

Morrison and Winston summarize the major economic explanations for the sad state of U.S. aviation performance: a lack of clear pricing signals at both airports and within the air traffic control system, a traditional over-reliance on administrative solutions to congestion issues, and the lack of clear market signals for runway investment. (Unfortunately, they did not include a discussion of FAA's proposed slot auctions at the New York area airports or the pricing proposals included as part of the Bush Administration's FAA reauthorization proposal. The manuscript had been prepared before either was announced. However, they declare that "[ $t]$ he relevant consideration in pricing air traffic control services is the marginal cost that a given flight imposes on the air traffic control system,..." which sets them apart from FAA, the Air Transport Association, and others.) 
The authors acknowledge the political resistance to privatization, and suggest that one way to build support would be to demonstrate the effects by designing experiments to provide evidence of how the change might affect carriers and passengers. In what may be the first major experiment in the United States, Chicago Midway was leased for \$2.5 billion in 2008 to a consortium lead by YVR Airport Services Ltd., an affiliate of the Vancouver Airport Authority, Citi Infrastructure Investors and John Hancock Life Insurance Co.

Gillen and Niemeier describe the shift to more market-oriented policies in ownership and management of airport infrastructure within the European Union (EU). The change, they say, reflects a position that airports can improve their efficiency and service to passengers and carriers under privatization. They trace the source of the change to a 1995 European Commission statement that infrastructure should be priced according to social marginal cost principles.

The authors provide a useful overview of different airport regulation models. Control over airport charges (i.e., charges for services like runways, gates, and apron use) varies extensively. Both cost-based and price-cap regulation schemes are discussed, as well as their major drawbacks. Cost-based regulations, for example, fail to provide the proper signals for pricing, since they provide no incentive for airports to minimize costs. Price-cap regulations are criticized for their short-term focus and lack of incentives to invest.

Gillen and Niemeier also include a discussion of EU approaches to capacity constraints. Many EU airports experience significantly more demand than capacity, and airport expansion is hindered by financial and political/environmental constraints. As a result, the EU rations capacity through a slot allocation process. The authors describe the features of this process, including how slots are obtained, grandfathering clauses, how new entrants are addressed, slot sales and trading, and hoarding.

Looking across the various approaches applied by EU member states, Gillen and Niemeier conclude that systems with independent regulators, incentive-based regulation, and dual tills have incentives to reduce X-inefficiency. There are incentives for price differentiation to increase traffic and to manage demand. ${ }^{1}$

Peter Forsyth describes airport regulatory policy and performance in Australia and New Zealand (A/NZ). These examples stand in contrast to the discussion of events in the EU, as demand for operations at $\mathrm{A} / \mathrm{NZ}$ airports tends to be far less than existing capacity, and thus raises questions about how to recover costs.

Forsyth highlights the question of what goals the governments sought to advance through their regulatory approaches. He argues that in A/NZ, the overall "light-handed" regulatory approach is oriented more toward keeping prices near costs than promoting efficiency. "Light-handed regulation is about process, not content - it is possible to have light-handed, cost-plus regulation."

The author provides a useful summary of efficiencies that must be considered with airports, in particular productive efficiency, allocative efficiency, ensuring that investment is neither inadequate nor excessive, and taking advantage of opportunities for commercial development. He extends that discussion into the "airport cost recovery problem," and relates it to pricing and single-till vs. dualtill charging mechanisms. ${ }^{2}$

The major shortcoming with the regulatory environment concerns investment incentives. Many airports are under pressure from local or regional interests to make "excessive investments," and those costs are passed on ultimately to passengers under cost-plus regulation. Forsyth thus considers the lack of incentives to get investment right to be the "least satisfactory aspect of current regulatory frameworks." If the regulatory approaches of both A/NZ could be revised, the author concludes that some disincentives for excessive investment need to be adopted.

Anne Graham provides a thorough overview of airport planning and regulation in the U.K. She highlights the changes in airport ownership and the government's regulation of airports following the Thatcher government's decisions to corporatize and privatize nationalized industries, such as utilities, communications, and transportation. 
Under the 1986 Airports Act, the government stated its policy that air transport should not be subsidized by the taxpayer and that airports should operate as commercial undertakings. The Act also allowed for the British Airports Authority (BAA) to become a private company - one eventually bought by the Spanish firm Ferrovial - and authorized the Civil Aviation Authority (CAA) to exercise economic regulation over airports.

Graham provides an overview of the price cap regulation $(R P I+/-X)$ that the CAA applies to airports and the effect of its use of single-till charging. ${ }^{2}$ She discusses major policy issues associated with the U.K.'s regulatory approach, focusing on the length of the planning process (the public inquiry into Heathrow's Terminal 5 lasted for 30 months and cost an estimated $£ 80$ million) and the effects of price-cap regulation on airport efficiency. Graham notes that for congested airports (the London airports in particular), prices that emanate from single-till charging schemes are inefficient, in that they do not reflect the economic value of using the airports. She also discusses the effect of RPI+/-X price caps' inevitable focus on short-term operational efficiencies at the expense of investment incentives.

Tretheway and Andriulaitis ${ }^{3}$ review the evolution of Canadian airport investment policy. Canadian airports were operated under a federal department that gradually found itself unable to finance needed capacity expansion. Facing looming budgetary pressures, the national government decided to "quasi-privatize" the airports by transferring them to local airport authorities that were established as non-profit entities. The authors trace the evolution of the airports' governance models and some of the major issues with devolving the airports, such as inequities between the airports in terms of rents paid back to the national government.

The authors discuss how the not-for-profit governance model - coupled with a policy goal of facilitating investment in airport infrastructure - proved to be inherently paradoxical. The government believed that the not-for-profit model would help ensure that airport prices and charges would remain reasonable. Because the airports lacked initial equity when quasi-privatized, their only ability to generate revenue needed for investment was gained by charging prices that allowed for an accumulation of net income (profits).

Tretheway and Andriulaitis pointed out that governments wishing to use a non-profit governance model in sectors requiring large capital investments should appreciate the implications that those actions may have for the need for pricing freedom and the possible intergenerational transfer of wealth.

The final two chapters discuss other parts of the globe with significantly different airport situations. Anming Zhang and Andrew Yuen's chapter describes airport policy and performance in mainland China and Hong Kong. Before the 1980s, virtually every aspect of aviation in China was under the control of the Civil Aviation Administration of China (CAAC), which was a department of the air force. This included not just the regulator, but also air traffic control, airport management, and airline operations. Zhang and Yuen discuss how aviation there was gradually liberalized, and what the effects have been on productivity, passenger growth, competition, and safety. They note, however, that because the state retains a controlling stake in key airports, efficiency remains a challenge.

Hong Kong International is obviously in a different situation than other Chinese airports; the discussion of HKIA centers more on the competition it increasingly faces from Guangzhou and Shenzhen for local traffic and other Asian airports, such as Singapore, Tokyo, and Seoul for connecting traffic.

Kenneth Button lastly provides a discussion of air transportation infrastructure in developing countries. He focuses largely on Africa and South America, and notes that they too are moving to liberalize the institutional environments in which air transport infrastructure services are delivered. Button's discussion highlights what little analysis has been published on these area's aviation systems, which makes it difficult to generalize or draw conclusions. The focus on many of these locations remains not on niceties of economic efficiency, but on the need to meet minimum standards of service, safety, and security. 


\section{Endnotes}

1. Airport charges are calculated using one of two general approaches: single- or dual-till. Under a single-till approach, nonaeronautical or commercial revenue is included with aeronautical revenues. A dual-till approach treats the two areas as separate financial entities.

2. This price cap system allows for price changes attributable to inflation (RFP being the retail price index) and changes in revenue in real terms (X). Price caps are applied to aeronauticalrevenue-per-passenger figures and the aeronautical revenue obtained from landing charges, passenger charges, and aircraft parking charges. Costs associated with security that airports normally pass through to consumers are excluded from price regulation.

3. Disclaimer: The author of this review works with both Messrs. Tretheway and Andriulaitis at InterVISTAS Consulting.

Steven Martin is senior vice president, government affairs and policy, at InterVISTAS-ga2 Consulting, Inc., in Washington, D.C. Martin oversees InterVISTAS' economics practice and provides management oversight of projects assessing the economic impact of international gateways and airports at various North American facilities. He is the principal investigator on a project for the Transportation Research Board (TRB) concerning air service development techniques that can be used at small community airports. He spent more than two decades at the U.S. Government Accountability Office, where he directed GAO's evaluations relating to transportation and commercial aviation. He is program chair for the International Aviation Club of Washington and a member of the Washington, D.C. chapter of the Transportation Research Forum. 